earlier work that showed that such children did not have an increased nocturnal urine output compared with that in controls. ${ }^{1213}$

To date few adverse effects with desmopressin have been reported. Because minor side effects are common with the tricyclic antidepressants and because they are dangerous drugs to have in households (because of accidental overdose) desmopressin may be a safer drug to use. At present its use in Britain is limited to four weeks because of a lack of data on its long term use. Many other countries have licensed desmopressin without restrictions on its length of use, and as more studies are completed it may well be that longer use will be allowed and indicated in Britain. If long term use or repeated courses of desmopressin are considered then comparative costs will become increasingly important. At present one week's treatment with imipramine may cost 10 pence whereas one week's treatment with desmopressin will cost between $£ 5$ and $£ 10$, depending on the dose used.

S R MEADOW Professor of Paediatrics J H C EVANS

Department of Paediatrics and Child Health,

St James's University Hospital,

Leeds LS9 7TF

1 Meadow SR. How to use buzzer alarms to cure bed wetting. Br Med $\mathcal{F}$ 1977; ii: 1073-5.

2 Azrin NH, Sneed TJ, Foxx RM. Dry-bed training. Behav Res Ther 1974;12:147-56.

3 Blackwell B, Currah J. The psychopharmacology of nocturnal enuresis. In: Kolvin I, Mackeith RC, Meadow SR, eds. Bladder control and enuresis. London: Heinemann, 1973:231-57.

4 Aladjem M, Wohl R, Boichis H, Orda S, Lotan D, Freedman S. Desmopressin in nocturnal enuresis. Arch Dis Child 1982;57:137-40.

5 Post EM, Richman RA, Blackett PR, Duncan KP, Miller K. Desmopressin response of enuretic children. Effects of age and frequency of enuresis. Am $\mathcal{F}$ Dis Child 1983;137:962-3.

6 Kjoller SS, Hejl M, Pedersen PS. Enuresis treated with minurin (DDAVP). A controlled clinical study. Ugeskr Laeger 1984;146:3281-2.

7 Dimson SB. DDAVP and urine osmolality in refactory enuresis. Arch Dis Child 1986;61:1104-7.

Wille S. Comparison of desmopressin and enuresis alarm for nocturnal enuresis. Arch Dis Child 1986;61:30-3.

9 Delaere KP, Striibos WE. Antidiuretic approach with DDAVP for nocturnal enuresis. Acta Urol Belg 1986;54:464-70.

10 Holt J, Borresen B. Enuresis nocturnal in school children in Bodø. A therapeutic trial with a vasopressin analog: desmopressin and imipramine. Tidsskrift for Den Norshé Laegeforening 1986;106:651-4.

11 Norgaard JP, Pedersen EB, Djurhuus JC. Diurnal antidiuretic levels in enuretics. 7 Urol 1985;134:1029-31.

12 Vulliamy D. The day and night output of urine in enuresis. Arch Dis Child 1956;31:439-43

13 Troup CW, Hodgson NB. Nocturnal functional bladder capacity in enuretic children. 7 Urol 1971;105:129-32.

\section{Monitoring resuscitation}

\section{How to start and monitor, and when to stop}

Difficulties arise in deciding whether to start resuscitation, when to stop, and whether the resuscitation attempt is proceeding satisfactorily. Research has been hampered by the lack of standardised formats for reporting incidents and of standardised treatments, but both are now available, which should improve collection of data.

For inpatients a decision should have been made beforehand about whether to resuscitate; the cardiac arrest teams should not have to make decisions in seconds, with little or no knowledge of patients and their illnesses. Four suggested potential reasons for limiting treatment are that the patient's health declines, the treatment is futile, the costs are too great, or the quality of life would be unacceptable. ${ }^{1}$ To decide whether to start resuscitation is most difficult when the patient is brought into an accident and emergency department having had a cardiac arrest outside hospital or when the arrest occurs within minutes of arrival, and such emergency decisions must be made in favour of a resuscitation attempt. ${ }^{2}$ Often basic facts such as the cause of the arrest, the patient's age, the length of cardiopulmonary standstill, and the history are not available, although a rapid history should be sought from the ambulance crew while a doctor seeks vital information from an accompanying relative. Clearly, resuscitation must not be delayed, but enthusiasm for a prolonged attempt should be tempered in the light of adverse features in the history.

Monitoring the effectiveness of efforts at resuscitation is important. If the patient survives without cerebral damage we might congratulate ourselves, and if the patient does not survive then we may console ourselves by assuming that survival was impossible. Without taking into account all the variables outcome can, however, be only a crude measure of the effectiveness of the various techniques. Comparison of outcome among various centres, or indeed within a single hospital, is meaningless unless a standardised reporting system is used. Zideman recognised this problem and recommended a standardised reporting format. ${ }^{3}$ The United Kingdom multicentre study of in hospital cardiopulmonary resuscitation initiated by the Resuscitation Council (United Kingdom), which uses a standardised reporting format, should be published shortly and will provide valuable data.

A finger on the carotid or femoral pulse is the usual method to monitor circulation, but is a palpable pulse a measure of circulation or merely a shock wave? Kouwenhoven et al may have been optimistic in suggesting that a systolic pressure of 60-100 $\mathrm{mm} \mathrm{Hg}$ was achieved during external cardiac massage, and they did not measure blood flow. ${ }^{+}$Most studies investigating blood flow during external cardiac massage have used animal preparations, and a comparative study of five techniques of external massage on dogs concluded that high impulse manual compression generated better haemodynamics than other methods. ${ }^{5}$ Chamberlain et al questioned the applicability of the animal model to resuscitation in humans, ${ }^{6}$ but the work of Maier $e t a l$ and Newton $e t a l^{5}$ was instrumental in the recent decision by the American Heart Association to recommend an increase in the rate of manual compression to 80-100 times per minute. Newton et al have recommended a clinical trial in humans to evaluate the effect of this change. ${ }^{5}$

The Resuscitation Council(United Kingdom) has suggested firm guidelines for managing the rhythms of ventricular fibrillation, asystole, and electromechanical dissociation ${ }^{8}$ that are commonly found in patients who have had a cardiac arrest, ${ }^{9}$ and the American Heart Association has issued detailed guidelines for drug use during cardiac arrest. ${ }^{9-13}$

The cause of the arrest, the response to treatment, and the age of the patient are all important factors to consider when deciding whether to abandon a resuscitation attempt. Bedell et al found no survivors among 294 hospital patients who had had cardiac arrest if the attempt continued for longer than 30 minutes. ${ }^{14}$

Standardised treatment protocols currently being revised by the Resuscitation Council (United Kingdom), together with data collected at resuscitation attempts, should define effective forms of treatment and patients most likely to benefit from resuscitation.

\section{DAVID V SKINNER}

Consultant in Accident and Emergency Medicine,

St Bartholomew's Hospital,

London EC1A 7BE

1 Lo B, Jonsen AR. Clinical decisions to limit treatment. Ann Intern Med 1980;93:764-8.

2 Fox M, Lipton HL. The decision to perform cardiopulmonary resuscitation. $N$ Engl $\mathcal{J ~ M e d}$ 1983;309:607-8

3 Zideman DA. Cardiopulmonary resuscitation - the need for national surveys. Journal of the World Association of Emergency and Disaster Medicine 1985;1:291-3.

4 Kouwenhoven WB, Ing, Jude JR, Knickerbocker GG. Closed-chest cardiac massage. FAMA 1960;173:1064-7.

5 Newton JR, Glower DD, Wolfe JA, et al. A physiologic comparison of external cardiac massage techniques. F Thorac Cardiovasc Surg 1988;95:892-901.

6 Chamberlain DA, Gattiker R, Hart HN, et al. Recent achievements and present controversies in cardiopulmonary resuscitation. Eur Heart f 1987;8:438-43. 
7 Maier GW, Newton JR, Wolfe JA, et al. The influence of manual chest compression rate on hemodynamic support during cardiac arrest: high-impulse cardiopulmonary resuscitation. Circulation 1986;74(suppl IV);51-9.

8 Evans TR, ed. $A B C$ of resuscitation. London: BMJ Publications, 1986.

9 Jaffe AS. Cardiovascular pharmacology I. Circulation 1986;74(suppl IV):70-4.

Guerci AD, Chandra N, Johnson E, et al. Failure of socium bicarbonate to improve resuscitation from ventricular fibrillation in dogs. Circulation 1986;74(suppl IV):75-9.

1 Otto CW. Cardiovascular pharmacology II: the use of catecholamines, pressor agents, digitalis and corticosteroids in CPR and emergency cardiac care. Circulation 1986;74(suppl IV):80-5.

Paraskos JA. Cardiovascular pharmacology III: atropine, calcium, calcium blockers and $\beta$ blockers. Circulation 1986;74(suppl IV):86-9.

3 Thompson BM, Steuven HS, Tonsfeldt DJ, et al. Calcium: limited indications, some danger. Circulation 1986;74(suppl IV):90-3.

4 Bedell SE, Delbanco TL Cook E, Epstein FH. Survival after cardiopulmonary resuscitation in the hospital. N Engl f Med 1983;809:569-75.

\section{Stepping carefully through trade union legislation}

\section{$B M A$ must be careful of infringement}

Could the BMA fall foul of trade union law through its campaign against the NHS white paper? The association is a trade union subject to the Trade Union Act 1913, which says that union funds must not be used to further political objects unless the objects have been approved by a ballot of members and payments are made out of a separate political fund. The leadership of the association is aware of this problem and has circulated advice.

Despite often criticising the government of the day the BMA has always maintained a neutral political stance. Unlike many of the large unions the association has never adopted political objects and maintains no political fund. Therefore it may not spend money on any of the activities spelt out in the act, as amended by the Trade Union Act 1984. The changes made by the Conservative government in 1984 cover almost every conceivable type of political activity-from providing financial support for members of parliament to paying for a brass band at a political rally.

The restriction that could trip up the BMA is the section that lays down that a union must not spend money, except from a political fund, "on the production, publication or distribution of any literature, document, film, sound recording or advertisement the main purpose of which is to persuade people to vote for a political party or candidate or to persuade them not to vote for a political party or candidate."

This would apply not only to staff but also to committees, subcommittees, divisions, regional craft committees, and local medical committees. The restriction does not apply to members of a union acting in their personal capacity.

The act tripped up the National and Local Government Officers' Association (NALGO) in 1987. The union, which had no political fund, was taken to court by two of its Conservative members who were trying to stop a $£ 1 \mathrm{~m}$ campaign arguing for more money to be spent on public services and timed to coincide with local elections and the run up to the general election. Leaflets targeted on marginal seats suggested that the Tory government was responsible for waiting lists, unemployment, and the state of the NHS. The High Court granted the injunction, declaring the campaign-which included specific references to voting in leaflets and posters: "You have a voice. You have a vote. Make people matter"; "Questions to ask before you vote"; and "Think before you vote"- unlawful despite a disclaimer that the union was not seeking or opposing the election of any group of candidates.

\section{BMA advice on campaigning}

BMA committees and subcommittees (including divisions, regional craft committees, and local medical committees) should not:

- Produce, publish, or distribute any document that attempts to persuade people to vote for a particular party or candidate or to dissuade them from voting for a particular party or candidate

- Publish material that gives voters grounds to assume that the BMA encourages them not to vote for a particular party or candidate

- In the run up to an election-including general elections, by elections, council elections, or European electionssupport a candidate in any way, including by canvassing, giving funds, or providing administrative help such as telephoning, fax facilities, printing, or photocopying

- Make any comment on any aspect of the BMA's campaign which could be associated with an election without first seeking guidance from the public affairs division.

Doctors using their own leaflets and posters as part of the NHS campaign must ensure that the BMA's name is not associated with any printed material-including videos, slides, and newspaper advertisements - if it could be interpreted as trying to influence the public on how to vote. Doctors must also remember the proscription on spending money on producing personal leaflets and posters.

In giving judgment ${ }^{1}$ the Vice Chancellor, Sir Nicolas Browne-Wilkinson, noted the timing of the campaign and emphasised that nothing in his judgment should be taken as suggesting that a publicity campaign organised by a union at times other than an election - and therefore at a time when the union could not directly or indirectly be inviting people to vote-would be unlawful merely because it expressed disapproval of the government's policy.

Sir Nicolas refused to rule on whether the campaign also breached section 75 of the Representation of the People Act 1983, another possible danger zone for BMA divisions and committees. This makes it a criminal offence before elections -including by elections, council elections, and European elections - for any person without the approval of a candidate's election agent to incur expenses with a view to promoting or procuring the candidate's election by holding public meetings or displays, issuing advertisements or circulars, or presenting views that might disparage other candidates.

The BMA, its committees, and its representatives need to be careful not to step over the boundary drawn by the Trade Union Act 1983 and use union funds in an attempt to influence votes. It need not, however, be troubled by visions of sequestration of its funds, as happened to the miners', print workers', and seamen's unions when they found themselves on the wrong side of the law in industrial disputes. Only a dissident member could take the association to court; the government has no right to do so. And the remedy is an injunction to stop the unlawful political activity. Only if the BMA defied such an injunction would it risk having its assets sequestrated.

Legal correspondent, $B M \mathcal{F}$

CLARE DYER

1 Paul and Fraser v NALGO. Industrial Relations L.aw Reports 1987:413. 